\title{
Rancang Bangun Instrumentasi Elektrokardiograf (EKG) dan Klasifikasi Kenormalan Jantung Pada Pola Sinyal EKG Menggunakan Learning Vector Quantization (LVQ)
}

\author{
Maulana $^{1}$, Hendrick $^{2}$, Ratna Aisuwarya ${ }^{3}$ \\ ${ }^{1,3}$ Sistem Komputer Fakultas Teknologi Informasi Universitas Andalas, Kampus Limau Manis, Padang, 25163, Indonesia \\ ${ }^{2}$ Teknik Elektro Politeknik Negeri Padang, Kampus Limau Manis, Padang, 25163, Indonesia
}

\section{ARTICLE INFORMATION}

Received: November 11,2017

Revised: February 20, 2018

Available online: March 29. 2018

\section{KEYWORDS}

EKG,LVQ,kelas,training,identifikasi

CORRESPONDENCE

E-mail: ratna.aisuwarya @ fti.unand.ac.id

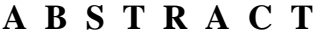

Electrocardiograph (ECG) is a recorder of human heart signals with signal output on a monitor or graph paper. The ECG records the measurement of the electrical activity of the heart from the surface of the body by a set of electrodes that are installed in such a way that reflects the tapping point activity. The pattern of ECG output signals in one heartbeat produces a pattern with a peak point $\mathrm{P}, \mathrm{Q}, \mathrm{R}, \mathrm{S}$ and $\mathrm{T}$ or $\mathrm{QRS}$ complex. ECG signal waveform results were analyzed using Learning Vector Quantization (LVQ) Artificial Neural Networks, and grouped into two classes, namely normal and abnormal heart patterns. The normal heart condition that is trained is a medically normal heart categorized as healthy as 10 data, while an abnormal heart (Heart, Coronary Heart, and Aortic Regurgutation) is 20 data. The LVQ method recognizes the input pattern based on the proximity of the two vectors, namely the vector of the input unit or neuron with the weight vector produced by each class. Online LVQ identification (using ECG) recorded from 25 direct trials resulted in $80 \%$ accuracy.

\section{PENDAHULUAN}

Pada dasarnya sebuah sebuah EKG yang digunakan tenaga medis terdiri atas seperangkat sensor elektroda yang dipasang pada bagian tubuh Elektroda tersebut kemudian dihubungkan pada penguat sinyal kecil yang kemudian diperkuat sampai beberapa kali bahkan ratusan kali. Ada beberapa hal yang menjadi kelemahan dari EKG ini yaitu pengalaman dan kemampuan para ahli untuk menganalisa kenormalan hasil rekaman jantung yang berbeda-beda. Oleh sebab itu perlu dipikirkan bagaimana jika EKG bisa menganalisis sendiri terkait normal atau tidaknya jantung. Hal ini akan memeberikan beberapa keuntungan diantaranya membantu mempercepat mengetahui normal atau tidaknya jantung seseorang.

Untuk bisa menghasilkan software yang dapat mengklasifikasikan kenormalan jantung, maka dirancanglah sebuah sistem kecerdasan buatan. Kecerdasan buatan yang dimanfaatkan adalah Jaringan syaraf tiruan (JST). JST yang dilihat dari fungsi atau struktur rancangan merupakan penyederhanaan dari model otak manusia dan merupakan suatu metode kecerdasan buatan komputasional berbasis pada model saraf biologis manusia sehingga komputer dapat menduplikasikan kecerdasan manusia. Jaringan Saraf Tiruan yang sering digunakan yaitu Learning Vector Quantization $(L V Q)$.
LVQ adalah suatu metode klasifikasi pola yang masing-masing unit output mewakili kategori atau kelompok tertentu. LVQ dikembangkan oleh Teuvo Kohonen dan merupakan algoritma terawasi (supervised) yang merupakan penurunan dari algoritma kohonen yang sifatnya tak terawasi (Unsupervised). Model jaringan ini banyak digunakan untuk diaplikasikan pada penyelesaian suatu masalah berkaitan dengan identifikasi, prediksi, pengenalan pola dan sebagainya.

\section{LANDASAN TEORI}

\subsection{Detak Jantung}

Pertama kali darah dari pembuluh darah vena masuk ke Atrium Kanan, kemudian menuju ke Ventrikel Kanan, kemudian menuju ke Paru- Paru, dimana dalam paru-paru ini terjadi pertukaran udara dari $\mathrm{CO} 2$ ke O2. Dari paru-paru darah menuju ke Atrium Kiri, kemudian menuju ke Ventrikel Kiri. Setelah itu darah dipompa menuju ke seluruh tubuh dan kepaladimana melalui pembuluh darah Aorta. Pembuluh darah Aorta sendiri terdiri dari berbagai cabang dimana urutan pembuluh yang terbesar sampai terkecil adalah: Arteri, Arteriol, dan Kapiler. Gambar dari alur tersebut dapat dilihat pada Gambar 1. 


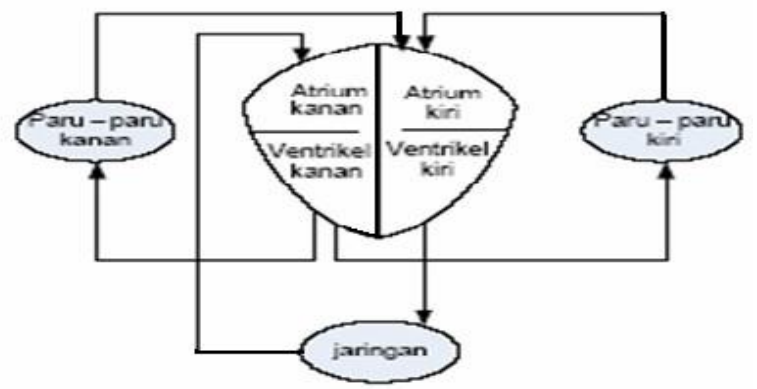

Gambar 1. Alur peredaran darah.

\subsection{Elektrokardiograf (EKG)}

EKG adalah pengukuran aktivitas listrikjantung yang dicatat dari permukaan tubuh oleh sekumpulan elektroda yang dipasang sedemikian rupa sehingga merefleksikan aktivitas dari berbagai titik sadapan. Sadapan biasanya dilakukan pada permukaan kulit, permukaan dada, kaki, dan tangan untuk mewakili sinyal jantung. Perbedaan antara peletakan sadapan EKG di dada dan di tangan dan kaki adalah hanya pada besar dan kecilnya amplitude sinyal, sedangkan bentuk sinyalnya tetap sama. Oleh karena itu bila pasien sinyal jantungnya lemah (amplitudonya kecil) maka perlu dilakukan pembesaran penguatan sinyal saja.

Elektrokardiograf merupakan peralatan. Pada umumnya yang dipakai adalah 12 sadapan yang dapat dikelompokkan menjadi 3, yaitu :

a. Sadapan baku (standart lead) atau dikenal dengan sadapan Einthoven, yaitu lead I, lead II dan

lead III.

b. Sadapan ditingkatkan (augment lead) atau sadapan Goldberger, yaitu sadapan aVR, aVL dan aVF.

c. Sadapan dada (precordial lead) atau sadapan Wilson, yaitu V1, V2, V3, V4, V5 dan V6.

\subsection{Pola Sinyal EKG}

\section{A. Pola Sinyal EKG Normal}

Bentuk gambaran umum pola sinyal normal jantung manusia :

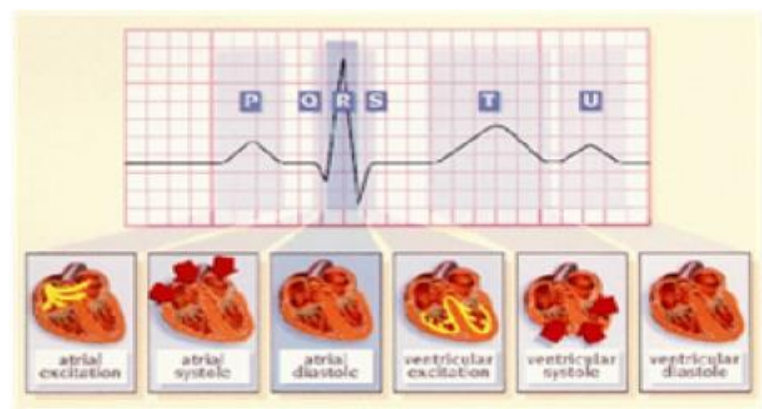

Gambar 2. Gambar EKG Normal.
- Gelombang P

Gelombang ini berukuran kecil dan merupakan hasil dari depolarisasi dari atrium kanan dan kiri . nilai normal interval $\mathrm{P}$ adalah kurang dari 0,12 detik.

- $\quad$ Segmen PR

Segmen ini merupakan garis iso-elektrik yang menghubungkan gelombang $\mathrm{P}$ pada QRS. Lama interval PR : $0,12-0,20$ detik.

- Gelombang kompleks QRS

Merupakan hasil depolarisasi dari ventrikel kanan dan kiri .lama interval QRS adalah 0,07-0,10 detik.

- $\quad$ Segmen ST

Segmen ini merupakan garis iso-elektrik yang menghubungkan gelombang QRS pada T.

- Gelombang T

Merupakan potensial repolarisasi dari ventrikel kanan dan kiri.

- Gelombang U

Gelombang ini berukuran kecil dan sering tidak ada, asal dari gelombang ini merupakan hasil repolarisasi dari atria yang sering tidak dikenali karena ukurannya kecil dan terbenam pada gelombang QRS

\section{B. Pola Irama EKG Tidak Normal}

Berikut ini adalah beberapa pola irama EKG yang tidak normal :

\section{- Regurgitasi Aorta}

Regurgitasi katup aorta adalah kembalinyadarah ke ventrikel kiri dari aorta selama diastol atau kebocoran pada katup aorta yang terjadi tiap kali ventrikel mengalami relaksasi, bentuk polanya seperti pada gambar 3 .

Gambar 3. Pola Irama EKG Regurgitasi Aorta

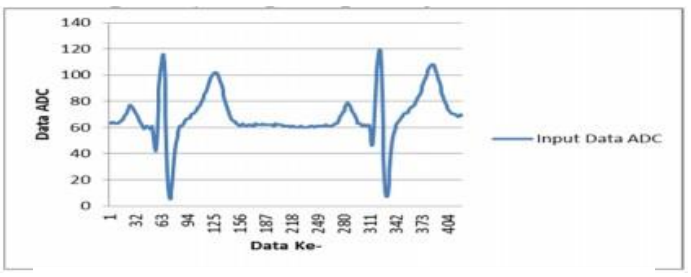

\section{- Jantung Koroner}

Penyakit Jantung Koroner adalah penyempitan pembuluh darah kecil yang memasok darah dan oksigen ke jantung. Ini disebabkan oleh pembentukan plak di dinding arteri, dikenal pula sebagai pengerasan arteri, bentuk polanya seperti pada gambar 4 .

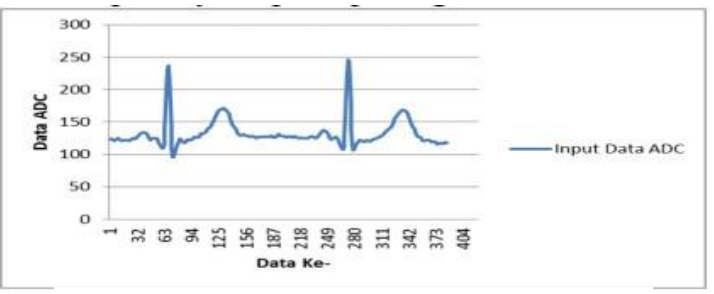

Gambar 4. Pola Irama EKG Jantung Koroner 


\section{- $\quad$ Congestive Heart Failure (CHF)}

Congestive Heart Failure (CHF) atau gagal jantung adalah keadaan patofisiologis berupa kelainan fungsi jantung, sehingga jantung tidak mampu memompa darah untuk memenuhi kebutuhan metabolisme jaringan atau kemampuannya hanya ada kalau disertai peninggian volume diastolik secara abnormal. Penamaan gagal jantung kongestif yang sering digunakan kalau terjadi gagal jantung sisi kiri dan sisi kanan, bentuk polanya dapat dilihat pada gambar 5 .

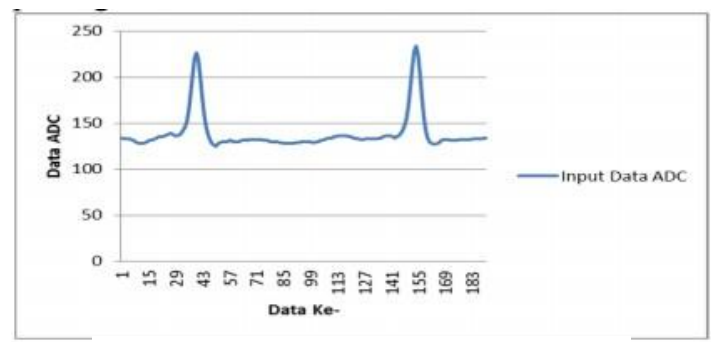

Gambar 5. Pola Irama EKG CHF

\subsection{Block Diagram QRS Detector}

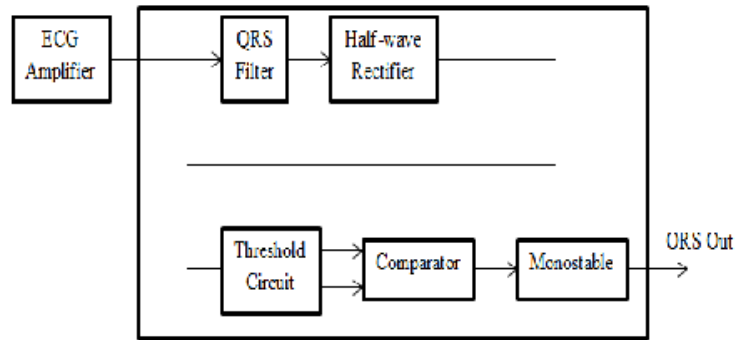

Gambar 6. Block Diagram of a QRS detector.

Gambar 6. menunjukkan dari sebuah blokdiagram dan schematic komplek dari sebuah pendeteksi QRS. Pendeteksi QRS terdiri dari 5 unit

1) ECG Amplifier, biasanya berada pada rentang $1 \mathrm{mV}$ dan memiliki frekuensi sekitar 0,05-100 Hz. Untuk memproses sinyal, dibutuhkan penguat. Penguatan sinyal untuk EKG bekisar 1000 kali dengan respon frekuensi sekitar 0,05-100 Hz.

2) QRS filter, kekuatan spectrum sinyal EKG memiliki noise sekitar $17 \mathrm{~Hz}$. Maka untuk mendeteksi komplek QRS, EKG harus melewati bandpass filter dengan pusat frekuensi sebesar $17 \mathrm{~Hz}$ dan bandwidth $6 \mathrm{~Hz}$.

3) Half-wave Rectified, QRS yang telah disaring (filtered) merupakan setengah gelombang telah diralat. Untuk selanjutnya dibandingkan dengan tegangan ambang yang dihasilkan oleh sirkuit detector.

4) Threshold Circuit. Puncak tegangan EKG yang telah diralat dan difilter disimpan pada kapasitor. Sebagian kecil dari tegangan (tegangan yang diralat) dibandingkan dengan keluaran EKG yang telah disaring dan diralat.

5) Comprarator. Pulsa QRS terdeteksi ketika tegangan ralat terlampaui. Kapasitor diisi lagi oleh tegangan ralat yang baru untuk setiap terbentuknya pulsa.

6) Monostable. Sebuah pulsa $200 \mathrm{~ms}$ dihasilkan untuk setiap komplek QRS yang terdeteksi.

\subsection{Digital Small Volume Patient Monitor OEM 07 ECG Module}

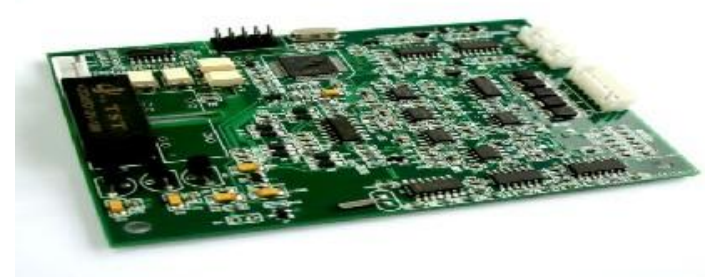

Gambar 7. Modul EKG

Digital Small Volume Patient Monitor OEM 07 ECG Module diproduksi oleh perusahaan dari Cina yang bernama Shanghai Berry Electronic Tech Co., Ltd. Modul instrumentasi EKG ini dirancang untuk mendapatkan sinyal-sinyal elektrik tiap jantung berdetak. Modul ini mempunyai lead sebanyak 5 yaitu I, II, III, AVL dan AVR.

\subsection{Learning Vector Quantization (LVQ)}

Learning Vector Quantization (LVQ) adalah suatu metoda klasifikasi pola yang masing- masing unit output mewakili kategori atau kelompok tertentu. Learning vector quantization dikembangkan oleh Kohonen dan menyimpulkan bahwa terdapat 3 jenis algoritma di dalam Learning vector quantization. LVQ ini termasuk kedalam supervised learning seperti yang tercantum didalam algoritma LVQ1. LVQ1 adalah versi pertama LVQ yang diciptakan oleh Kohenen.

Proses training LVQ1 dilakukan dengan menggunakan input sebagai bobot awal yang dipilih secara random. LVQ1 juga sedikit mirip dengan Kohonen SOM, yang membedakan adalah LVQ1 menggunakan supervised learning sedangkan Kohonen SOM menggunakan unsupervised learning.

Vektor input pada LVQ1 disimbolkan sebagai xi dan output neuron dianggab sebagai pemenang berdasarkan aturan yang sama seperti yang diterapkan dalam Kohonen SOM. Tapi hal yang mendasar menjadi perbedaan antara Kohonen SOM dan LVQ1 adalah cara melakukan weight update.

Proses update wj pada LVQ1 adalah sebegai berikut ini :

1. Jika kelompok yang diwakili oleh weight vector sama dengan kelompok input maka, $\mathrm{Cwj}=\mathrm{Cxj}$, maka

$$
\begin{aligned}
& w_{j(k+1)=} w_{j}(k)+\mu(k)\left[x_{i}-w_{j}(k)\right] \\
& \text { Dimana } 0<\mu(k)<1(\text { learning rate }
\end{aligned}
$$
parameter )

2. Jika $\mathrm{Cwj} \neq \mathrm{Cxi}$ maka

$$
w_{j(k+1)}=w_{j}(k)+\mu(k)\left[x_{i}-w_{j}(k)\right]
$$

Jadi jika kelompok bernilai benar, maka update weight dilakukan terpisah dengan update weight yang salah. Berikut algoritma LVQ1 (M,Ham, 2001) 
1. Inisialisasi nilai awal vektor bobot $\mathrm{wj}(0)$, learning rate parameter $\mu(0)$ dan $k=0$.

2. Periksa kondisi berhenti, jika bernilai salah lanjutkan dan jika benar, keluar dari prosedur berikut.

3. Untuk setiap vektor training $\mathrm{xi}$, lakukan instruksi nomer 4 dan 5

4. Tentukan indek vektor bobot input $(\mathrm{j}=\mathrm{q})$ dengan menggunakan rumus

$$
\underset{\min =\| x_{i}-}{w_{j}(k)} \|_{\text {dari }}^{2}
$$

dengan menggunakan akar dari rumus jarak Euclidean.

5. Update bobot vektor $\mathrm{wq}(\mathrm{k})$ dengan cara sebagai berikut Jika

$$
\mathrm{C}_{\mathrm{wq}}
$$
$=$ $\mathrm{C}_{\mathrm{Xi}}$ maka

$w_{q(k+1)}=w_{q}(k)+\mu(k)\left[x_{i}-w_{q}(k)\right]$

$$
\text { Jika } \quad \mathrm{C}_{\mathrm{wq}} \neq \quad \mathrm{C}_{\mathrm{xi}} \quad \text { maka }
$$$$
w_{q(k+1)}=w_{q}(k)-\mu(k)\left[x_{i}-w_{q}(k)\right]
$$

6. Update $\mathrm{k} \leftarrow \mathrm{k}+1$, kurangi learning rate parameter dan kembali ke langkah 2. Pengurangan learning rate $\mu$ bisa dilakukan berdasarkan nilai $\mathrm{k}$ dengan menggunakan persamaan :

$$
\mu(k)=\mu(k-1) /(k+1) \quad k>0
$$

\section{METODOLOGI PENELITIAN}

\subsection{Prosedur Penelitian}

Prosedur penelitian yang akan dilakukan dapat digambarkan pada blok diagram berikut ini :

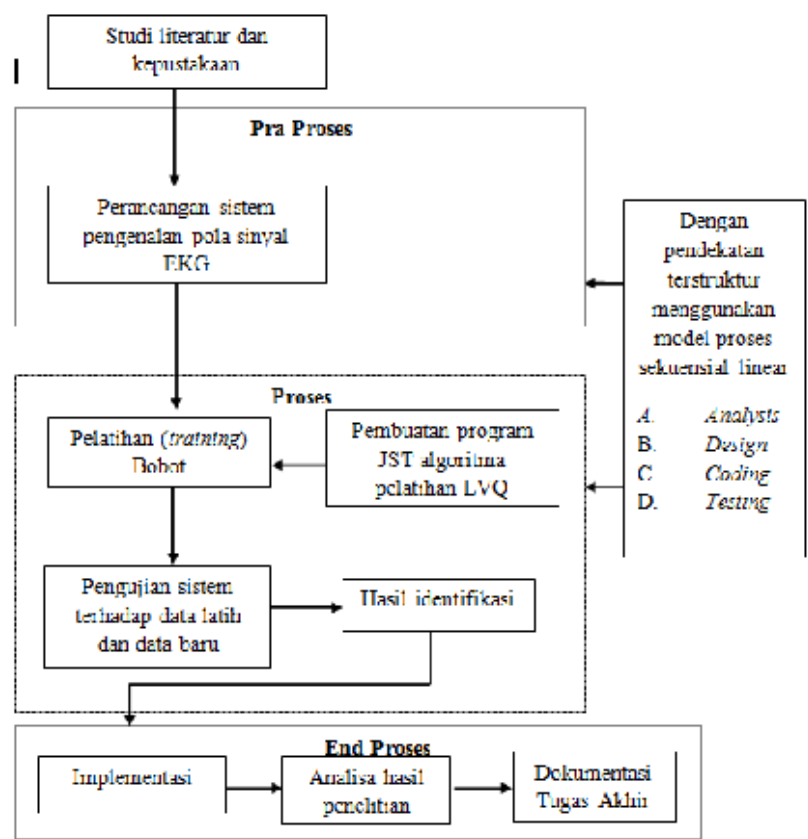

Gambar 8. Prosedur penelitian.

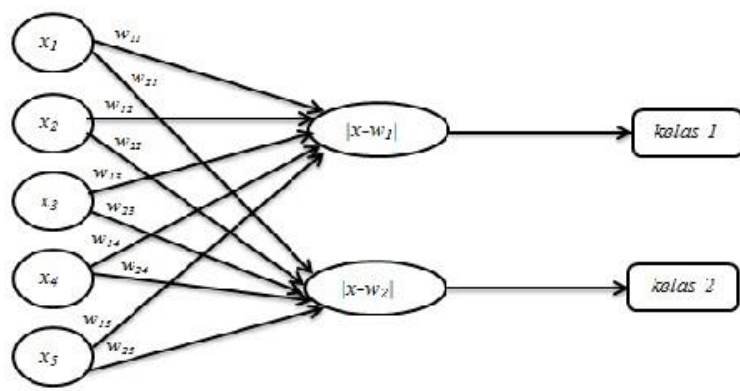

Jaringan Syaraf Tiruan LVQ

- Rancangan arsitektur Jaringan Syaraf Tiruan Learning Vector Quantization (LVQ) seperti pada gambar di bawah ini.

- $\quad$ Rancangan Pembelajaran JST LVQ (Tarining $L V Q)$

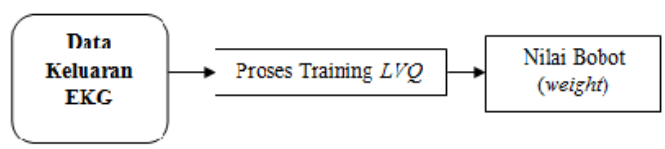

- $\quad$ Rancangan Identifikasi JST $L V Q$

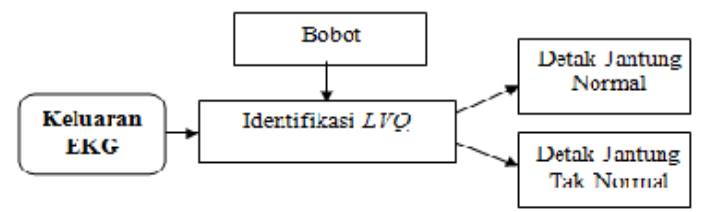

\section{HASIL DAN PEMBAHASAN}

\subsection{Pengujian Modul EKG}

Pengujian dilakukan untuk mengetahui apakah program dan perancangan dapat berjalan sebagaimana yang diharapkan. Selain itu akan dilakukan analisa terhadap data-data yang diperoleh dari sistem saat dijalankan. Alat ini bisa digunakan untuk mendeteksi pola irama jantung sebagaimana digunakan utnuk kebutuhan medis.

Untuk proses pengambilan data pola irama jantung, dilakukan pemasangan EKG pada tubuh manusia dengan menggunakan 5 titik penempelan Elektroda yaitu tangan kanan dan kiri, kaki kanan dan kiri, dan dada. Proses tersebut dapat dilihat pada gambar berikut: 


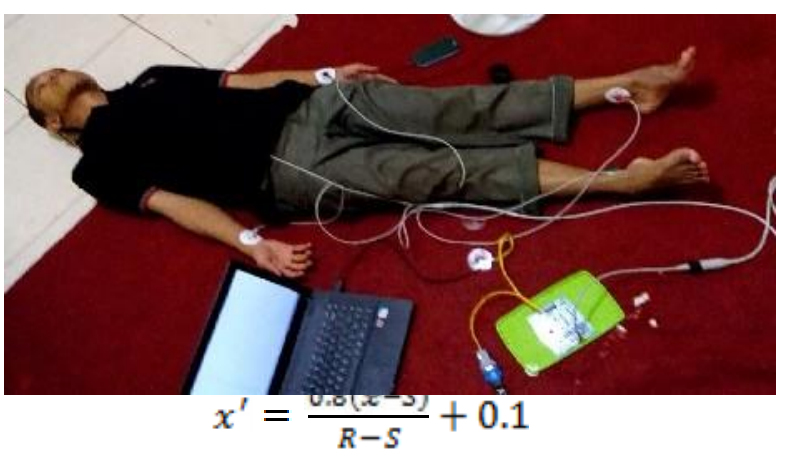

\section{Gambar 9. Pemasangan EKG}

Proses di atas bertujuan untuk mendapatkan rekaman data pola jantung berupa data ADC. Sedangkan hasilnya dapat dilihat pada gambar berikut

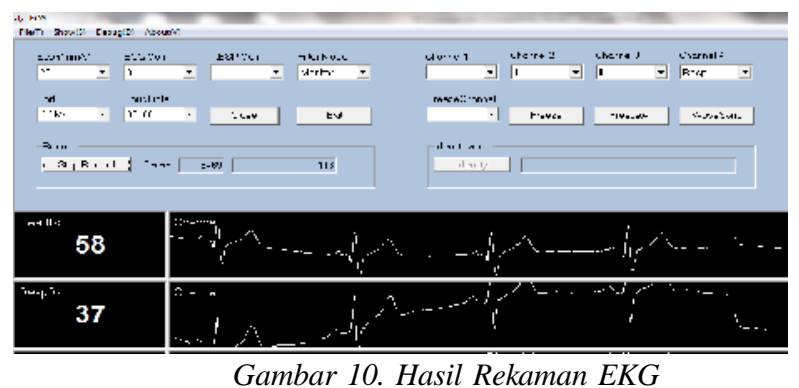

Untuk keterangan singkat terkait interface dari gambar di atas

- $\quad$ Scan $(\mathrm{mm} / \mathrm{s})$ merupakan pilihan kecepatan pola EKG yang direkam.

- EKG Gain merupakan besar kecilnya bentuk gelombang, semakin besar angka yang dipilih maka akan semakin besar bentuk gelombangnya.

- Filter Mode dalam hal ini ada beberapa pilihan yaitu operation, monitor, diagnose.

- Channel merupakan pilihan lead yang akan digunakan.

- Port merupakan komunikasi serial dari modul EKG yang terbaca pada saat dihubungkan dengan PC.

- Baudrate merupakan jumlah data per detik yang dapat ditransfer melalui sebuah interface serial. Baudrate yang digunakan adalah 38400 .

- Record digunakan untuk melakukan perekaman data.

- Identification merupakan hasil untuk menampilkan informasi jantung normal dan jantung tidak normal.

\subsection{Analisa Jaringan Syaraf Tiruan}

\section{1) Normalisasi Data}

Fungsi normalisasi berdasarkan referensi dari buku Jaringan Syaraf Tiruan dan Pemrogramannya Menggunakan
Matlab. Fungsi aktivasi yang digunakan pada JST ini adalah fungsi sigmoid biner. Maka data harus dinormalisasikan karena range keluaran fungsi aktifasi sigmoid adalah $[0,1]$ sehingga data bisa ditransformasikan ke interval [0,1]. Namun, data akan ditransformasikan ke interval yang lebih kecil, misalnya [0.1,0.9] karena fungsi sigmoid merupakan fungsi asimtotik yang nilainya tidak pernah mencapai 0 ataupun 1.

Jika S pada komplek QRS sebagai data tertinggi dan $\mathrm{R}$ adalah data maksimum, transformasi linear yang dipakai untuk mentransformasikan data ke interval $[0.1,0.9]$ adalah

Keterangan : $\mathrm{x}=$ data $\mathrm{ADC}$

$$
\begin{aligned}
& \mathrm{R}=\text { data maksimum } \\
& \mathrm{S}=\text { data minimum }
\end{aligned}
$$

Contoh : Didapatkan nilai $\mathrm{P}=130, \mathrm{Q}=114, \mathrm{R}$ $=247, \mathrm{~S}=80, \mathrm{~T}=157$, normalisasinya sebagai berikut

- $\quad \mathrm{P}: x^{\prime}=(0.8(130-80) /(247-80))+0.1$

$$
=(40 / 167)+0.1=0.3395
$$

- $\mathrm{Q}: x^{\prime}=(0.8(114-80) /(247-80))+0.1$

$$
=(27.2 / 167)+0.1=0.2629
$$

- $\mathrm{R}: x^{\prime}=(0.8(247-80) /(247-80))+0.1$

$$
=0.8+0.1=0.9
$$

- $\quad \mathrm{S}: x^{\prime}=(0.8(80-80) /(247-80))+0.1$

$$
=0+0.1=0.3395
$$

- $\quad \mathrm{T}: x^{\prime}=(0.8(157-80) /(247-80))+0.1$

$$
=(61.6 / 167)+0.1=0.4687
$$

Hasil normalisasi data untuk masing-masing jantung dapat dilihat sebagai berikut,

\section{Normalisasi Data Jantung Normal}

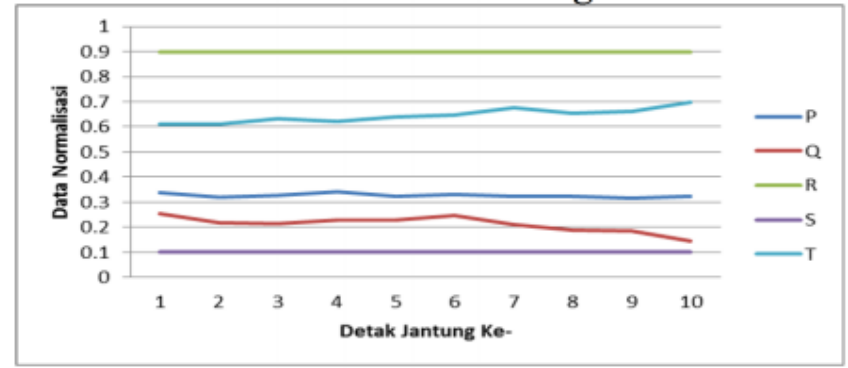

Gambar 4.12. Grafik Normalisasi Data Jantung Normal 
2. Normalisasi Data Jantung Tidak

Normal

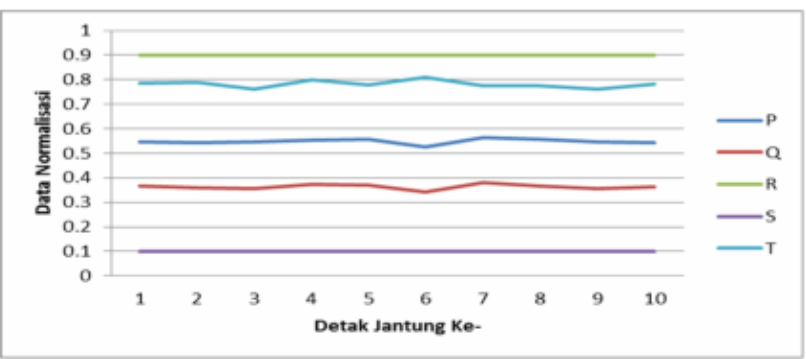

Gambar 4.13. Grafik Normalisasi Data Jantung Regurgitasi Aorta

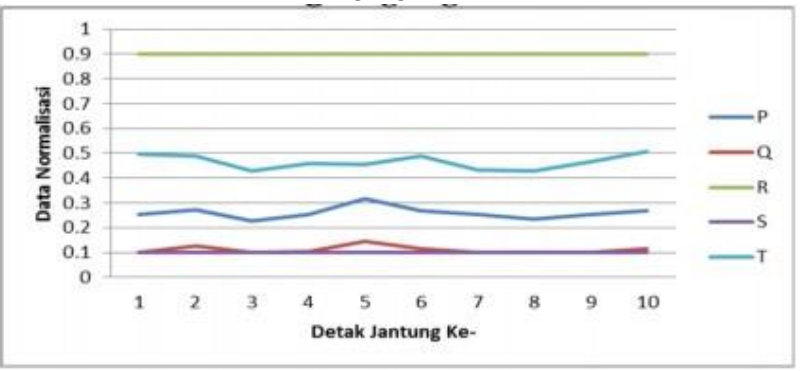

Gambar 4.14. Grafik Normalisasi Data Jantung Koroner

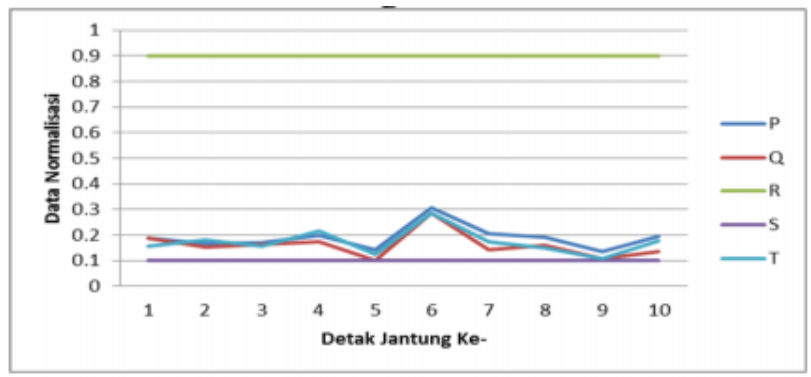

4.15. Grafik Normalisasi Data Jantung CHF

\section{2) Training atau Pelatihan Jaringan Saraf Tiruan}

Training atau pelatihan dilakukan untuk mendapatkan nilai bobot yang akan digunakan pada proses indetifikasi JST. Data yang dilatih berjumlah 20 data untuk kondisi jantung tidak normal dan 10 data untuk data jantung normal. Training dibagi ke dalam 2 kelas yaitu normal dan tidak normal serta untuk target data yang diinginkan berdasarkan kelas sesuai dengan tabel 4.1.

Tabel 4.1. Target Kelas

\begin{tabular}{|l|c|}
\hline \multicolumn{1}{|c|}{ Output } & $\begin{array}{c}\text { Target } \\
\text { Kelas }\end{array}$ \\
\hline Normal & 1 \\
\hline Tidak Normal & 2 \\
\hline
\end{tabular}

Dari data yang diperoleh tersebut dilakukanlah training dengan metode LVQ (Learning Vector Quantization) untuk mendapatkan nilai bobot akhir dari masing- masing kelas normal dan tidak normal berdasarkan QRS EKG-nya. Training dilakukan secara terpisah dengan program yang sudah dirancang berdasarkan algoritma LVQ untuk mendapatkan W atau bobot pada gambar 4.16 .

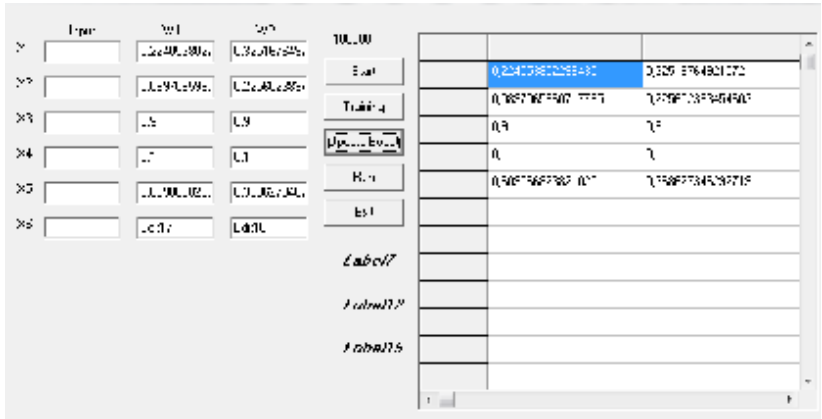

Gambar 4.16. Program Training $L V Q$

Tabel 4.7. Nilai Bobot Akhir Training Data

\begin{tabular}{|c|c|c|c|c|c|}
\hline \multirow{2}{*}{ Output } & \multirow{2}{*}{$\begin{array}{l}\text { Trger } \\
\text { kelas }\end{array}$} & \multicolumn{4}{|c|}{ Bobox Slltir Training } \\
\hline & & $?$ & Q & $\mathbb{R}$ & $\begin{array}{ll}\text { S } & \text { I }\end{array}$ \\
\hline Somel & 1 & 0.241 & 0,0857 & 0,9900 & $0,10000,009$ \\
\hline Thel Nerral & 2 & 0,3252 & 0,256 & $0,9 \mathrm{~N}:$ & $0,1000 \quad, 3688$ \\
\hline
\end{tabular}

\section{3) Identifikasi Hasil EKG secara Online}

Identifikasi yang outputnya dihasilkan dari pembacaan langsung saat modul EKG-nya dioperasikan. Untuk mendapatkan hasil identifikasi, terlebih dahulu direkam 2 komplek QRS-nya, seperti pada gambar berikut.

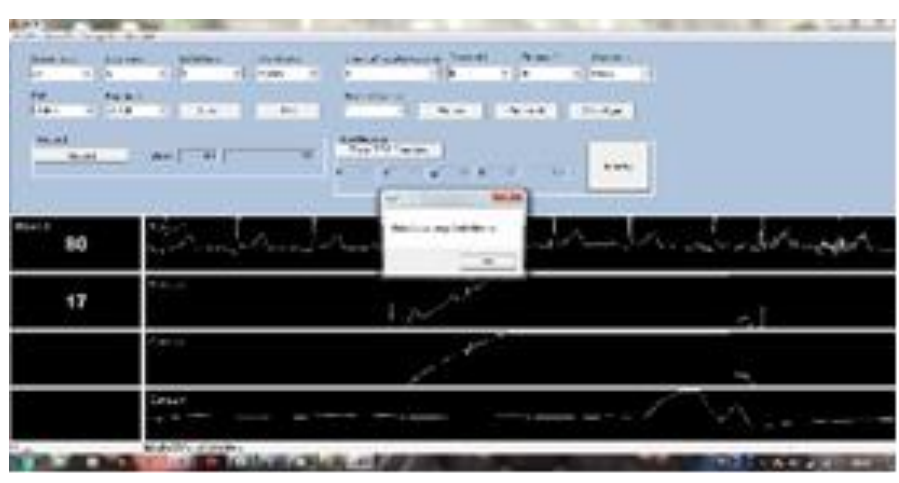

Gambar 4.17. Hasil Identifikasi EKG secara online

Berikut ini hasil pengujian secara langsung pada orang yang jantungnya normal dan tidak normal : 
Tabel 2. Pengujian Online:

\begin{tabular}{|c|c|c|c|c|c|c|c|}
\hline \multirow{2}{*}{ No } & \multicolumn{5}{|c|}{ Input Data Uji } & \multirow{2}{*}{$\begin{array}{c}\text { Kelas } \\
\text { Uji }\end{array}$} & \multirow{2}{*}{$\begin{array}{l}\text { Target } \\
\text { Kelas }\end{array}$} \\
\hline & $\mathbf{P}$ & $\mathbf{Q}$ & $\mathbf{R}$ & $\mathrm{S}$ & $\mathbf{T}$ & & \\
\hline 1 & 113 & 110 & 210 & 121 & 158 & 1 & 1 \\
\hline 2 & 129 & 124 & 224 & 123 & 161 & 1 & 1 \\
\hline 3 & 143 & 119 & 221 & 128 & 183 & 1 & 1 \\
\hline 4 & 131 & 119 & 202 & 109 & 163 & 1 & 1 \\
\hline 5 & 120 & 109 & 204 & 93 & 147 & 1 & 1 \\
\hline 6 & 112 & 89 & 172 & 90 & 144 & 1 & 1 \\
\hline 7 & 126 & 117 & 199 & 111 & 152 & 2 & 1 \\
\hline 8 & 119 & 104 & 180 & 93 & 146 & 1 & 1 \\
\hline 9 & 138 & 123 & 203 & 134 & 169 & 1 & 1 \\
\hline 10 & 122 & 110 & 209 & 109 & 158 & 1 & 1 \\
\hline 11 & 134 & 121 & 186 & 124 & 157 & 1 & 1 \\
\hline 12 & 128 & 114 & 186 & 117 & 139 & 2 & 1 \\
\hline 13 & 137 & 123 & 193 & 124 & 162 & 1 & 1 \\
\hline 14 & 127 & 114 & 191 & 115 & 154 & 1 & 1 \\
\hline 15 & 126 & 106 & 182 & 114 & 152 & 1 & 1 \\
\hline 16 & 114 & 97 & 173 & 104 & 123 & 2 & 1 \\
\hline 17 & 131 & 109 & 250 & 73 & 155 & 2 & 2 \\
\hline 18 & 130 & 114 & 247 & 80 & 157 & 2 & 2 \\
\hline 19 & 137 & 122 & 250 & 81 & 156 & 2 & 2 \\
\hline 20 & 130 & 67 & 250 & 73 & 152 & 2 & 2 \\
\hline 21 & 136 & 73 & 250 & 78 & 141 & 2 & 2 \\
\hline 22 & 128 & 72 & 245 & 71 & 128 & 2 & 2 \\
\hline 23 & 140 & 78 & 250 & 84 & 156 & 2 & 2 \\
\hline 24 & 111 & 89 & 214 & 41 & 114 & 2 & 2 \\
\hline 25 & 117 & 87 & 168 & 51 & 147 & 2 & 2 \\
\hline & & 2xesen & $\operatorname{siA}$ & rasi & Data & & $88 \%$ \\
\hline
\end{tabular}

modul EKG sudah sesuai dengan hasil yang diharapkan, yaitu bisa mengelompokkan jantung normal dan jantung tidak normal.

\subsection{Saran}

Setelah mengadakan penelitian tentang "Rancang Bangun Instrumentasi Elektrokardiograf (Ekg) Dan Klasifikasi Kenormalan Jantung Pada Pola Sinyal Elektrokardiograf (Ekg) Dengan Menggunakan Learning Vector Quantization ( $L v q)$ " ini penulis melihat bahwa banyak hal yang harus di perbaiki dan lengkapi untuk kelanjutan penelitian berikutnya, untuk itu penulis mempertimbangkan beberapa saran yang diperlukan dalam proses perbaikan pada tugas akhir ini yaitu sebagai berikut :

1. Untuk mendapatkan akurasi data yang lebih

bagus dan lebih sempurna, dilakukanlah pengambilan data dari sampel yang lebih banyak, terutama pada orang sakit jantung, karena akan semakin banyak variasi data yang akan dikelompokkan.

2. Untuk memudahkan pembacaan pola yang

lebih akurat dari sebuah data ditambahkanlah metode FFT (Fast Fourier Transform), karena metode FFT dapat memunculkan pola sebenarnya sehingga pola yang data yang diperoleh lebih akurat dan noise dapat dikurangi.

3. Pengambilan data secara online dalam identifikasi EKG sedikit rumit karena harus mendapatkan dua nilai komplek QRS, sehingga dalam pengambilan data sebaiknya dilakukan dalam jangka iterasi tertentu yang dipertihungkan agar operator EKG tidak direpotkan dalam pengambilan data.

\section{KESIMPULAN DAN SARAN}

\subsection{Kesimpulan}

Setelah melakukan pengujian dan Analisa pada penelitian ini, maka dapat ditarik kesimpulan bahwa:

1. Pengujian data dilakukan dengan 3 cara yaitu pengujian data training, pengujian data acak nontraining, dan pengujian secara online. Pengujian data training LVQ memiliki keakuratan $83,3 \%$ dan pengujian data non- training memiliki keakuratan 91,43\%. Untuk pengujian data EKG secara online yang direkam dari 25 kali percobaan langsung mengahasilkan keakuratan $80 \%$. Dari hasil tersebut LVQ mampu mengidentifikasi kenormalan jantung dengan baik.

2. Klasifikasi kenormalan pola sinyal EKG menggunakan

\section{DAFTAR PUSTAKA}

1. Basaruddin, T, dkk. 2011. Klasifikasi Beat Aritmia Pada Siyal EKG Menggunakan Fuzzy Wavelet Learning Vector Quantization. Universitas Negeri Surabaya, Surabaya.

2. Darmawansyah, dkk. 2006. Pembuatan Elektrokardiograf (EKG) Teknologi Hibrid Menggunakan Komponen Surface Mounting Device (SMD). Jurnal. Universitas Gadjah Mada. Yogyakarta.

3. Fitrian, Nur. 2007. Bab II. Skripsi, Universitas Sumatera Utara, Medan. 
4. Hidayati, Nurul, Budi Warsito. Prediksi Terjangkitnya Penyakit Jantung Dengan Metode Learning Vector Quantization.2010. Universitas Diponegoro, Semarang.

5. http://www.forumsains.com/artikel/94/?print diakses tanggal 10 September 2013.

6. Purnamasari, Rita, dkk. Perhitungan Denyut Jantung Berdasarkan Sinyal EKG Berbasis FPGA. Jurnal. Institut Teknologi Telkom. Bandung.

7. Rahmat. 2009. Perancangan dan Realisasi Elektrokardiograf Menggunakan Jaringan Syaraf Tiruan Untuk Identifikasi Kelainan Jantung. Jurnal. Politeknik Negeri Padang. Padang. 